\title{
PELA MÃO DO DEVIDO PROCESSO LEGAL SUBSTANCIAL: A SUPREMA CORTE E A CONSOLIDAÇÃO DO CONSTITUCIONALISMO LAISSEZ-FAIRE.
}

\author{
BY THE HAND OF SUBSTANTIVE DUE PROCESS OF LAW: THE SUPREME \\ COURT AND THE LAISSEZ-FAIRE'S CONSTITUTIONALISM CONSOLIDATION.
}

\author{
${ }^{1}$ Paulo Roberto Barbosa Ramos \\ ${ }^{2}$ Regina Lúcia Gonçalves Tavares
}

\section{Resumo}

Este trabalho tem o propósito de fazer, a partir de uma revisão bibliográfica, uma abordagem sobre o manejo da cláusula do devido processo legal, em sua feição substancial, numa investigação sobre o seu uso pela Suprema Corte dos Estados Unidos durante os anos de 1895 a 1937, período no qual se adotou uma ideologia mais econômica às causas constitucionais, a fim de se justificar a política financeira de um período no qual aquele país buscava se solidificar internamente e implementar sua hegemonia no cenário internacional.

Palavras-chave: Direito Constitucional; Devido processo legal substancial; Constitucionalismo laissez-faire.

\begin{abstract}
This work is intended to make an approach, from a literature review, to the management of the due process clause in its substantial feature, in an investigation about it's manner by the Supreme Court of the United States during the years 1895-1937, in which time was adopted a more economic ideology to constitutional causes, in order to justify the financial policy of a time when that country was seeking to solidify internally and implement its hegemony in the international arena.
\end{abstract}

Key-words: Constitucional Right; Substantive due process of law; Laissez-faire constitucionalism.

\footnotetext{
${ }^{1}$ Pós-Doutor Direito Constitucional - Faculdade de Direito da Universidade de Granada, (Espanha). Coordenador do Mestrado em Direito e Instituições do Sistema de Justiça na Universidade Federal do Maranhão, UFMA - MA, (Brasil). Promotor de Justiça MPMA. E-mail: paulorbr@uol.com.br

${ }^{2}$ Mestranda em Direito e Instituições do Sistema de Justiça pela Universidade Federal do Maranhão, UFMA MA, (Brasil). Professora de Direito Processual Civil na Universidade Ceuma, CEUMA - MA, (Brasil).E-mail: rlg.t@hotmail.com
} 


\section{INTRODUÇÃO}

A Constituição Federal do Brasil, em seu artigo $5^{\circ}$, inciso LIV, nos traz a garantia do devido processo legal, como a fornecer um molde de solução jurídica justa às mais diversas espécies de demandas, na busca de prevenir a arbitrariedade do direito.

Como cláusula constitucional, o devido processo legal pode ser, e tem sido muito frequentemente em nossa jurisprudência, abordado por sua dimensão processual (procedural due processo of law), segundo a qual permite-se seja resguardada uma atuação processual atenta às garantias que concedam às partes em litígio um tratamento isonômico.

Por outro lado, a mesma cláusula se revela, igualmente, em uma dimensão capaz de permitir uma abordagem substancial desta garantia e, quando assim revestida, admite um controle pelo judiciário da atividade legislativa, que assim busca analisá-la a partir de critérios de razoabilidade e racionalidade de seus propósitos.

A jurisprudência da Suprema Corte dos Estados Unidos é fonte rica de análise da cláusula do devido processo legal em seu aspecto substancial, presente na $5^{\mathrm{a}}$ e $14^{\mathrm{a}}$ Emendas da Constituição daquele país.

Partindo do famoso caso Marbury v. Madson (1803), marco jurisprudencial inaugural a partir do qual, formalmente, a Corte Suprema chamou para si o dever judicial de determinar o significado da Constituição, nesta tarefa, passou ela a dar a $5^{\mathrm{a}}$ e a $14^{\mathrm{a}}$ Emendas, no que tange ao manejo da ferramenta do devido processo legal, dimensões que atendessem à ideologia sustentada por seus membros, de acordo com suas distintas fases.

Neste trabalho, se buscará, pela mão do devido processo legal substancial, compreender como a Suprema Corte dotou de significado constitucional determinadas liberdades econômicas, a fim de atender à política do laissez-faire que dominava o cenário estadunidense entre os anos de 1895 a 1937.

Para o cumprimento deste objetivo, far-se-á uma rápida apresentação do contexto histórico que, decerto, contextualiza o momento político vivido pela Suprema Corte no final do século XIX e inicio do século XX, qual seja entre aquele deflagrado pela política de reconstrução de um país recém-saído de uma guerra civil, e seu comportamento permissivo 
em relação às leis do mercado e do crescimento do comércio, das corporações e das indústrias e, décadas depois, aquele cenário impregnado pelo excesso de produção e saturação das políticas de consumo, como relevantes causas geradoras da grande depressão sobre a qual houve se estabelecido a política do New Deal.

Utilizando como leading case o caso Lochner, busca-se dar contorno à expressão do devido processo legal substancial, a partir da postura adotada pela Suprema Corte, igualmente com o auxílio de outros casos escolhidos não com o propósito de exaurir, mas de ilustrar em que medida aquela cláusula constitucional foi manuseada para servir de esteio aos arranjos que oportunizaram a configuração do constitucionalismo laissez-faire.

\section{DELINEAMENTOS HISTÓRICOS PARA UM RECORTE TEMPORAL: A SUPREMA CORTE DOS ESTADOS UNIDOS DE 1895 A 1937}

Como órgão a ocupar o vértice do Judiciário Federal, a Suprema Corte estadunidense tem, ao longo dos anos, exercido um papel fundamental no sentido de que suas decisões têm significativamente moldado os contornos da sociedade norte-americana, quando exercem o papel de vetor pelo qual importantes questões são colocadas em evidência na agenda nacional. Esta constatação pode ser ratificada na análise do papel da Suprema Corte entre os anos de 1895 a 1937.

Como protagonista na modelagem da sociedade americana, ao longo das décadas, a Suprema Corte tem realizado uma obra de mão dupla, quando, uma vez se alimentando da conjuntura histórica respectiva pela qual contribui para a conquista de direitos, de outra banda, ao oferecer sua opinião acerca das questões que lhe são submetidas, finda por remodelar as ações sociais e políticas realizadas pelos outros poderes, a partir do que define como constitucional.

A análise que ora se propõe não pode passar ao largo da conjuntura histórica vivida pela sociedade estadunidense do final do século XIX e inicio do século XX. Com efeito, o fim da Guerra Civil, ou Guerra de Secessão, travada entre os anos de 1861 a 1865, na qual os estados agrícolas do sul escravista foram vencidos pelo norte industrial, permitiu a superação dos antagonismos que deram origem àquele cisma (ainda que não superada, mas recrudescida a questão racial), pelo que, naquelas circunstâncias, passaram os Estados Unidos a se 
preocuparem com sua política de desenvolvimento. De fato, ratificada a soberania nacional de "uma União indestrutível, formada por estados indestrutíveis" (SCHWARTZ, 1966. p. 50) - o sul e sudeste, e seu potencial agrícola, passaram a ser celeiro do norte e nordeste, quando vivenciavam um processo de crescente industrialização, pelo que, neste propósito, as políticas governamentais, tanto no âmbito da federação, quanto no âmbito dos Estados, buscaram implementar esta parceria mediante o aumento da produção industrial e da tecnologia a lhes favorecer um maior desempenho, construção de ferrovias a possibilitar o transporte e comércio, mecanização da agricultura e redimensionamento do conceito e utilização de mãode-obra, não mais escrava, mas integrante de um novo sistema de mercado a demandar novas configurações de relações de trabalho, da qual faziam parte também os imigrantes: uma fase de reconstrução.

Neste ambiente de ressignificação das políticas públicas adotadas pelo governo estadunidense, a Constituição dos Estados Unidos é acrescida de significativas emendas ao seu texto. A $14^{\mathrm{a}}$ emenda, por exemplo, ilustra a ação do legislativo a definir a cidadania, tanto no âmbito federal, quanto no âmbito dos estados e a submissão dos cidadãos a igual proteção das leis, sujeitando os poderes constituídos à cláusula do devido processo legal, assim manifestando uma política de controle sobre as ações dos Estados, no âmbito do cerceamento às liberdades, que, de início, pudessem servir de obstáculo ao plano de reconstrução e fortalecimento da União. É o que se extrai da conclusão de Bernard Schwartz, na obra em que analisa o Direito Constitucional americano:

\begin{abstract}
Deve-se notar que a Carta de Direitos contém limitações ao Govêrno federal. Após a Guerra Civil, as emendas XIV e XV à Constituição estabeleceram a proteção judicial federal para o cidadão contra o seu Govêrno estadual. Os estados foram proibidos de 'restringir os privilégios ou imunidades dos cidadãos dos Estados Unidos; nem qualquer estado privará qualquer pessoa da vida, liberdade ou propriedade sem processo legal regular; nem negará a qualquer pessoa dentro de sua jurisdição igual proteção da leis'. SCHWARTZ, 1966. p. 268)
\end{abstract}

Era preciso garantir o funcionamento do sistema econômico, com vistas ao fortalecimento financeiro dos Estados Unidos, sob os auspícios liberais da livre iniciativa, tornando-a desembaraçada dos empecilhos das políticas governamentais. Era preciso conceder determinados privilégios à ação empreendedora dos americanos, neste sentido, conferindo à $14^{\mathrm{a}}$ emenda uma interpretação que a fizesse proteger as corporações ${ }^{3}$, de modo que, em questões econômicas e sociais, se pudesse conferir maior proteção aos

\footnotetext{
${ }^{3}$ Santa Clara County v. Southern Pacific R. Co., 118 U.S. 394 (1886) - A Corte, neste caso, reconheceu serem as Corporações 'pessoas' dentro da intenção da respectiva cláusula contida na Seção 1, da 14a Emenda.
} 
empreendimentos e à propriedade privada, dando-se à liberdade o sentido de liberdade de contratar e à igualdade, a concepção de uma igualdade econômica: assim se delineava a doutrina de um constitucionalismo laissez-faire junto ao judiciário federal norte-americano, atrelado a uma concepção de Estado Liberal.

Neste ponto, a Corte Suprema exerce papel fundamental, qual seja o de estabelecer a linha divisória entre os poderes central e aqueles exercidos pelos Estados, dentro de suas respectivas competências, manipulando o texto constitucional para este propósito. Toma-se, assim, a Constituição como lei fundamental pela qual se conjugam os dogmas da supremacia nacional e do federalismo dualista, para a manutenção do princípio federativo, sob uma conjuntura social advinda de uma política de fortalecimento do mercado. Uma difícil equação.

Numa espécie de movimento pendular, no exercício daquela função interpretativa de resolução dos conflitos entre a autoridade federal e a estadual, a Suprema Corte vezes acentua a aplicação de um ou de outro daqueles dogmas, a atender os propósitos da classe detentora do poder econômico, assim condicionada por fatores históricos, políticos e sociais. Schwartz prossegue:

Isso, de fato, era exatamente o que exigiam os defensores do laissez-faire. Para êles, o sistema econômico só poderia funcionar eficientemente se tivesse permissão para operar livremente de qualquer interferência governamental. $O$ conceito de federalismo dualista, tal como foi aplicado pela Côrte Suprema, era um complemento necessário do laissez-faire nos Estados Unidos. (SCHWARTZ, 1966. p. 69)

Assim, naquele recorte temporal, a Corte Suprema assimilou um perfil pelo qual revelava uma preocupação com questões iminentemente econômicas em detrimento daquelas relacionadas às liberdades civis individuais, nesta tônica limitando a atuação do Estado, acenando uma ideologia de individualismo, a atender os reclames do mercado, com vistas à eficiência dos meios de produção, mesmo que à custa dos interesses coletivos.

Por isto, de 1895 a 1937, posicionou-se a Suprema Corte, ainda que não de maneira uniforme $^{4}$, no sentido de pouco interferir no exercício das liberdades de contratar e na disposição acerca da propriedade privada, neste sentido distinguindo-se das duas primeiras fases que lhe antecedem ${ }^{5}$, quando remodela o conceito de federalismo dualista, este outrora

\footnotetext{
${ }^{4}$ Muller v. Oregon, 208 U.S. 412 (1908) - em que a Corte reconheceu a constitucionalidade de lei do Estado de Oregon limitadora da jornada de trabalho feminina.

${ }^{5}$ Distingue o Professor CORWIN grosso modo, na interpretação da Constituição pela Corte Suprema, tomando como ponto de referência os poderes do governo e as liberdades individuais, quatro períodos: 1) Até a morte de MARSHALL, em 1835, ou "Domínio do Diploma Constitucional" propriamente dito; 2) da presidência de
} 
compreendido a partir de uma interpretação iminentemente normativa da Constituição, por meio da qual os justices da Suprema Corte, no primeiro e segundo períodos de sua história, decidiam no sentido de garimpar seu real significado, qual seja aquele almejado pelos Pais Fundadores: "no ingênuo pressuposto de que o direito, escrito nas tábuas sagradas, era um sistema completo e perfeito" (BIDDLE, apud, RODRIGUES, 1992. p. 103).

Nesta terceira fase, o papel exercido pela Suprema Corte, como guardiã do texto constitucional, foi aquele de concretizar os propósitos da Constituição Federal, inaugurando assim um ativismo que atendia ao modo do espírito liberal da época. Esta distinção, acerca do novo temperamento da Corte, se acha bem definida por Lêda Boechat Rodrigues, quando esta, em sua obra A Corte Suprema e o Direito Constitucional Americano, analisa o terceiro período daquela casa, nominando-o de "governo de juízes":

Colocando-se na posição de declaradores de um direito natural acima da própria
Constituição, os juízes daquele tribunal passaram a superconstitucionalidade das
leis, em vez de limitar-se a dizer de sua simples constitucionalidade ou da
competência do legislador, sob o império da Constituição, para adotar tal ou qual
medida. As leis não eram mais declaradas inválidas, em sua maioria, por
incompatibilidade com os textos da Constituição e os processos por ela
estabelecidos, mas por incompatibilidade com os grandes princípios superiores a
mesma. O principal resultado dêsse controle da superconstitucionalidade das leis
pela Côrte Suprema, nessa fase, foi emancipá-la do documento constitucional, pois
ela não se limitava a aplicar regras legais estritas às questões constitucionais, mas
agia como um departamento político com poderes de Govêrno. (RODRIGUES,
1992. p. 100)

O conceito de federalismo dualista atingiu seu estágio de maior maturidade, expressando o conservantismo da Corte para, algumas décadas depois, numa ideia de evolução orgânica de uma política de governo, ao final daquele período, entrar em declínio. De fato, após décadas de crescimento econômico e prosperidade financeira, sobreveio a Grande Depressão de 1929, fato que findou por arrefecer a limitação até então exercida pela Corte no aceno de doutrinas que restringiam a ação dos poderes governamentais em detrimento da economia privada. Isto se deu a partir de seu confronto com o New Deal, segundo Lawrence Baum:

Até o final dos anos 30, a longa história de conservantismo da Corte poderia ter sugerido que era improvável uma mudança importante em sua posição. Contudo, poucos anos depois de seu confronto com o New Deal, a Corte mudou drasticamente a sua posição ideológica. Esta mudança refletiu-se tanto no tratamento por ela dado

TANEY (1835) até cerca de 1895. É o período por excelência da "Teoria Constitucional"; 3) De 1895 até mais ou menos 1937, ou período do judicial review puro e simples, em que a Corte Suprema exerceu em toda a sua extensão o controle de constitucionalidade das leis, num sentido de proteção exacerbada do laissez faire econômico; 4) o período atual, a partir de 1937, caracterizado pela substituição de uma "Constituição de Direitos" - direitos dos Estados e dos indivíduos - por uma "Constituição de Poderes" do governo. (CORWIN, apud, RODRIGUES, 1992. p. 16) 
às questões econômicas como em suas posições a respeito das questões referentes às liberdades civis. (BAUM, 1985, p. 276)

Sucede que, ainda no início do século XX, os Estados Unidos, com economia em expansão, depararam-se com a necessidade de abastecer a Europa em guerra, o que viabilizaria um ainda maior crescimento industrial e a concretização do sonho americano de hegemonia no mercado mundial, possibilitada por uma expansão industrial intensa a abastecer tanto o mercado externo, quanto o mercado interno, numa política de aumento de consumo que cunharia a expressão 'american way of life', a deflagrar o ingresso do norte-americano em um mercado de ações em ascensão.

Contudo, ao final da década de 20, já com a Europa reerguendo sua produção industrial e arrefecendo no que tange à importação da produção norte-americana, situação esta que surge conjugada com a saturação do consumo interno, possibilitaria uma reunião de fatores a irromper a grande depressão sobre a até então ascendente economia estadunidense. Rodrigues assim o explica:

Quando após longo período de economia ascendente e de prosperidade, veio a
Grande Depressão de 1929, cujos efeitos se prolongaram por alguns anos, reinam o
mal-estar, o desânimo e o desespero. Eleva-se ràpidamente o número dos sem-
trabalho, atingindo, em 1932, a 10 milhões. O terror do desemprego - das maiores
causas de sofrimento dos Estados Unidos, ao lado da enfermidade física e da doença
mental - ronda as imaginações, permanentemente ansiosas. Sem a perspectiva das
horas de trabalho, alongam-se interminável e insuportavelmente as horas de lazer. O
problema, além de econômico, é também moral. (RODRIGUES, 1992, p. 114)

Este é o cenário pelo qual, eleito em 1932 o Presidente Franklin Delano Roosvelt, buscou-se a introdução de reformas na política econômica e social americana, com a edição de leis que redimensionassem as políticas voltadas à agricultura, ao trabalho e à indústria, regulamentando-as. Era o New Deal ${ }^{6}$.

Com efeito, estabelecido o ano de 1937 como um marco temporal pelo qual a Suprema Corte abandona a doutrina do federalismo dualista, manifestada pela exigência de "uma dicotomia completa do poder estadual e federal" (SCHWARTZ, 1966, p. 206), toma-se aquele ano como inaugurador de um quarto período da Suprema Corte, em que um novo federalismo conforma-se num grau de maior extensão de controle governamental, possibilitado pelo New Deal, como política de reação à grande depressão, num intento de

\footnotetext{
${ }^{6}$ Ao fim de 100 dias, haviam sido introduzidas reformas substanciais na vida econômica americana. Em outubro os desempregados rediziam-se a seis milhões e no fim do ano o dólar valorizara-se de 33\%. Conquistou o Presidente a confiança popular e a malquerença dos homens de negócio.( RODRIGUES, 1992, p. 115)
} 
reorganização da economia estadunidense levada a cabo pelo então recente eleito presidente Roosevelt.

\section{A JURISPRUDÊNCIA DE 1895 a 1937: os julgamentos que definem o controle de constitucionalidade sob o espírito do laissez-faire}

A composição da Suprema Corte em seu terceiro período teve como ocupantes, na posição de Chief Justices, Melville Weston Fuller (1888 a 1910), Edward Douglas White (1910 a 1921), William Howard Taft (1921 a 1930) e Charles Evans Hughes (1930 a 1941), muito embora outros membros tenham merecido grande destaque, ante seus posicionamentos que dissidiam da ideologia do Tribunal àquela época, a exemplo dos Justices Oliver Wendell Holmes, Louis Dembitz Brandeis e Benjamin Nathan Cardozo (RODRIGUES, 1992).

O período de que se cuida é conhecido como um período de transição, que se caracteriza por uma jurisprudência restritiva da intervenção dos estados e da União na economia. Era a doutrina do constitucionalismo laissez-faire a produzir decisões que abrigavam amplamente a liberdade de contrato, como regra fundamental, que só poderia ser desprestigiada ou restringida pela via da exceção. Neste aspecto, o Justice Oliver Wendell Holmes (RODRIGUES, 1992, p. 131), juiz de visão mais progressista, dissidia da postura conservadora de seus pares, por entender que a Constituição dos Estados Unidos estaria sendo manejada pela Corte para ratificar determinadas opiniões pessoais dos julgadores e suas predileções econômicas.

Esta dissidência não tinha como fundamento a interpretação da Corte dada à cláusula do devido processo legal, uma vez que seus membros consentiam no fato de que ao due process of law, necessário era conferir-lhe uma interpretação que não condicionasse a lei aos sedimentos históricos de sua formulação, tal qual a vontade do legislador, mas manejá-la no sentido de se investigar a norma a partir de sua exequibilidade. Sob esta concepção mais ampla da cláusula do devido processo legal não havia dissidência. De fato, divergiam os membros da Corte, de 1895 a 1937, no sentido em que, enquanto a maioria admitia, a doutrina da notificação judicial, onde qualquer restrição às liberdades contratuais deveria ser justificada ante a presença de estrita excepcionalidade, a minoria aceitava o princípio da constitucionalidade da lei (CORWIN, apud, RODRIGUES, 1992, p. 132), pela qual sua razoabilidade era presumida. É sobre esta metodologia de exame do devido processo legal substancial que se discorrerá, a seguir. 


\subsection{A liberdade de contrato e a doutrina da notificação judicial: a "Era Lochner"}

O mais emblemático caso que ilustra o pensamento da Suprema Corte, em compreender a liberdade de contrato como regra geral a ser aplicada a título de metodologia interpretativa das normas infraconstitucionais, no exercício da judicial review, foi o caso Lochner v. New York (1905), assim tomado como o mais expressivo paradigma do constitucionalismo laissez-faire.

Naquele caso, Joseph Lochner, contratando um padeiro para trabalhar mais de sessenta horas por semana em seu estabelecimento comercial, teria violado uma lei do Estado de Nova York que proibia jornada superior a 10 horas de trabalho por dia nas padarias, e, por isto, foi condenado pelo judiciário estadual. Ascendido o caso à Suprema Corte, neste julgamento, concluiu-se que a lei do Estado de New York limitava gravemente o direito ao trabalho, em prejuízo da liberdade de contrato, esta entendida a partir de uma interpretação razoável da $14^{\mathrm{a}}$ emenda, segundo a qual nenhum Estado pode privar qualquer pessoa da vida, liberdade ou propriedade sem o devido processo legal.

Entendeu a Corte que o direito de comprar ou vender o trabalho é parte desta liberdade protegida pela Constituição, e que a mera preocupação em resguardar o trabalhador contra trabalhos insalubres, ainda que inerentes ao seu poder de polícia, não poderia fazê-lo o Estado, impedindo o direito ao trabalho, sem ferir o devido processo legal. Assim, era o substantive due processo of law utilizado como instrumento, do qual se valia a Suprema Corte para implantar uma ideologia hegemônica de proteção ao mercado, para dar um sentido de exequibilidade às leis desde que estas se justificassem por padrões diferenciados que admitissem sua constitucionalidade. Tratava-se de um poder quase legislativo, conferido à Corte por esta cláusula interpretativa.

Porquanto, anulando precedentes em que considerava presumida a constitucionalidade de leis estaduais editadas no manejo de seu poder de polícia - a exemplo do caso Holden v. Hardy (1898), em que julgou ser exercício válido do poder de polícia do Estado de Utah, portanto em conformidade com a $14^{\mathrm{a}}$ Emenda, o de limitar em 8 horas diárias o trabalho nas minas; e do caso Mugler v. Kansas (1887), quando conferiu constitucionalidade à legislação estadual, no exercício dos poderes de polícia do Estado, que ao seu turno proibiu o fabrico e venda de bebidas alcoólicas, porque prejudicial à saúde, à moral ou à segurança da comunidade -, a Suprema Corte, no caso Lochner, substituiu aquele 
entendimento pela doutrina da notificação judicial, "segundo a qual cumpria ao Estado provar a necessidade das medidas restritivas da liberdade de contrato" (RODRIGUES, 1992, p. 130).

A postura doravante assumida pela Suprema Corte, uma vez influenciada pela doutrina do laissez-faire, foi a de, num viés conservador dos poderes econômicos dominantes, dar uma interpretação à $14^{\mathrm{a}}$ emenda, com o suporte da cláusula do devido processo legal substantivo, para compreendê-la como limitadora do poder legislativo estadual, desta forma categorizando o questionado bem-estar público na condição de direito fundamental, mas em posição de submissão em relação às liberdades privadas, como por exemplo, a liberdade de contrato e sua manifestações na esfera trabalhista.

Muito embora esta já fosse a tônica que vinha sendo adotada pela Corte, antes do constitucionalismo laissez-faire atingir seu ápice, neste período a cláusula do due process of law tornou-se "instrumento ilimitado de avaliação da constitucionalidade não só das leis estaduais como das leis do Congresso, através do exame de seu acôrdo com a razão (reasonableness)" ${ }^{\prime \prime}$ : em outras palavras, as normas, porquanto apreciadas em sede de judicial review pela Corte Suprema, deveriam passar por um teste de razoabilidade para obterem o selo de constitucionalidade:

Em conseqüência da doutrina moderna do due processo of law como "lei razoável", o controle judicial deixou de ter limites definidos e definíveis; e embora varie consideravelmente, em cada caso, o reexame a que a Côrte Suprema submeterá a justificativa de fato de uma lei, sob as cláusulas de due process da Constituição, essa matéria depende, em última análise, apenas do arbítrio da própria Côrte e nada mais. (CORWIN, s/d, p. 306)

Trata-se de uma postura em que o julgador, buscando apurar a constitucionalidade de determinada norma, faz uso do princípio do devido processo legal substantivo para, transpondo seu significado literal, com vistas à sua formal adequação com a letra da Constituição, analisar os propósitos desta norma, assim submetendo-a a um filtro de razoabilidade $^{8}$, pelo qual, a depender da natureza do direito sobre o qual se discute, os julgadores o farão sob padrões mais rígidos (escrutínio estrito) ou mais suaves (escrutínio frouxo).

\footnotetext{
${ }^{7}$ Pela aplicação da "regra da razão" (rule of reason), a decisão judicial envolvia, na realidade, o julgamento baseado em considerações de ordem social e econômica, a cláusula do processo legal regular, entendida como proteção substantiva, atribuiu aos tribunais poder quase legislativo (RODRIGUES, 1992, p. 139)

${ }^{8} \mathrm{O}$ traço realmente distintivo da Côrte Suprema como órgão governamental é o de que a sua constituição muda, de regra, muito gradualmente, ficando ela, durante intervalos consideráveis, sob a influência de determinada 'filosofia social', cuja aplicação nos casos importantes, torna-se perfeitamente possível por parte daqueles que seguem o trabalho da Côrte com algum cuidado. (CORWIN, s/d, p. 305)
} 
Na terceira fase da Suprema Corte, qual seja aquela compreendida entre os anos de 1895 a 1935, o devido processo legal substancial era envolvido pela concepção do Estado Liberal, onde notório era o desenvolvimento de uma filosofia permissiva em relação às liberdades de contratar e negociar, esta manifestada a partir de decisões restritivas da capacidade regulamentadora dos Estados.

É o caso Lochner, conquanto, emblemático em demonstrar o manejo do devido processo legal para a apreciação da lei do Estado de Nova York, que lhe deu suporte, pelo qual restou-lhe rejeitada a constitucionalidade, à luz da $14^{\mathrm{a}}$ Emenda, na aplicação do escrutínio estrito para atender com rigor o direito às liberdades econômicas, em prejuízo das outras garantias fundamentais, numa espécie de bloqueio às legislações sociais. $\mathrm{O}$ sentido dado à liberdade pela Suprema Corte, era iminentemente econômico. O sentido dado à proibição de sua privação pela $14^{\mathrm{a}}$ emenda era, evidentemente, manobrado pela ferramenta do devido processo legal substancial, o de adequá-lo aos propósitos do capitalismo.

\subsection{Cláusula de Comércio e Cláusula de Contrato - concepções amplas de liberdade e propriedade pela fórmula do due processo of law}

Numa interpretação da $5^{\mathrm{a}}$ e da $14^{\mathrm{a}}$ emenda, a partir do sentido que se buscava dar à vaga previsão do que efetivamente consistisse o devido processo legal instituído naqueles dispositivos da Constituição estadunidense, a postura adotada pela Corte, durante o período de 1895 a 1937, foi aquele em que, pautado na doutrina da notificação judicial, deu margem à consolidação do constitucionalismo laissez-faire, o que seja, tratar a Constituição a partir de premissas liberais. Neste entendimento, a validade do ato legislativo, quanto aos critérios de se aferir sua razoabilidade a partir da metodologia proposta pela cláusula do devido processo legal substancial, "invoca a ideia de que a liberdade é a regra e a restrição a exceção" (CORWIN, s/d, p. 267)

Sempre vencidos os justices Holmes e Brandeis, por divergirem na compreensão da razoabilidade das legislações estaduais, no manejo da cláusula do devido processo legal substancial, já que, como minoria, aceitavam o princípio da constitucionalidade da lei (CORWIN, apud, RODRIGUES, 1992, p. 132), pela qual sua razoabilidade seria presumida, pelo que acreditavam:

As mutáveis condições sociais exigiam crescente regulamentação governamental nos negócios e que a Côrte só devia fulminar de inconstitucionalidade, em face da 
cláusula do due process, as leis que nêles interferissem arbitrária ou irrazoàvelmente, sob pena de se tornar, em certos casos, uma superlegislatura. (RODRIGUES, 1992, p. 107)

Todas as garantias instituídas para a proteção da propriedade das pessoas individualmente, também destinar-se-iam às Coorporações (Santa Clara County v. Southern Pacific R. Co. - 1886). A intromissão dos Estados na liberdade das empresas, no sentido de limitar suas atividades, deveria ser estabelecida por lei que atendesse ao conteúdo da cláusula do devido processo legal substancial, construída a partir do que se tomasse por sensato aos olhos do Estado Liberal. A partir desta concepção estavam definidas as bases jurídicas entendidas como necessárias à reconstrução da sociedade norte-americana saída da Guerra Civil, em meados do século XIX e nas três primeiras décadas do século XX.

É sob esta opinião que as limitações ao comércio e às organizações coletivas de trabalho eram vistas com a pecha de criarem obstáculos ao capital circulante. De fato, a Sherman Antitrust Act ${ }^{9}$, de 1890, foi aplicada contra os sindicatos, por exemplo, no caso Loewe v. Lawlor (1908), em que se considerou o arranjo de trabalhadores como forma de truste a criar empecilho ao livre fluxo do comércio (RODRIGUES, 1992, p. 125)

No caso Adair v. United States (1908), a Suprema Corte julgou inconstitucional a Seção 10, da Erdman Act, de 1898, assim considerando-a invasora da liberdade de contrato e do direito de propriedade garantidos pela $5^{\mathrm{a}}$ Emenda, chegando inclusive a considerar repugnante a disposição daquela legislação federal que buscava proibir os contratos yellow $\operatorname{dog}^{10}$, como fórmula encontrada pelo Congresso de mitigar as convulsões trabalhistas no setor ferroviário.

Naquele caso, considerando o teor da $5^{\mathrm{a}}$ Emenda, de que ninguém poderia ser privado da liberdade ou da propriedade sem o devido processo legal, a Suprema Corte fez uso do substantive due processo of law para lhes justificar um novo poder de revisão, qualificado pelos doutrinadores da época como "usurpação do Supremo" que, para alguns, só poderia ser detida mediante um reforma estrutural de suas prerrogativas. Ressalte-se, naquele contexto, o debate entre Charles Beard, da Universidade de Columbia e Edward Corwin, de Princeton,

\footnotetext{
${ }^{9}$ Aprovada em 1880 pelo Congresso dos Estados Unidos para proibir o truste no âmbito federal, assim regulamentando o comércio interestadual, a impedir que arranjos de empresas consolidadas em grupos exercessem o controle sobre os lucros com o comércio. (Cf. Estados Unidos. Sherman Antitrust Act -1890)

${ }^{10}$ Consistiam os contratos yellow dog aqueles configurados pela exigência posta aos trabalhadores das estradas de ferro de não se filiarem a uniões trabalhistas, sob pena de ameaça de demissão (Cf. RODRIGUES, 1992, p. 133)
} 
acerca da intenção dos Pais Fundadores em outorgar poderes de revisão ao judiciário (BEARD, 1962, p. 31-35).

No caso United States v. E. C. Knight Co. (1895), a American Sugar Refining Company, exercendo o monopólio sobre o negócio do açúcar refinado nos Estados Unidos, através da compra de refinarias em outros estados, e assim obtendo o controle de sua produção, obteve da Suprema Corte a opinião de que a fórmula legal do antitruste não poderia ser aplicável ao truste do açúcar, por não possuir aquela atividade relação direta com comércio entre os estados ou com nações estrangeiras e que o poder da União, conferido pelo texto constitucional, qual seja o de regular o comércio, é aquele concernente ao transporte das mercadorias e não ao seu fabrico (RODRIGUES, 1992, p. 123)

A combinação de truste visava o ganho privado e não o comércio, por isto inaplicável a Lei Sherman para o caso.

Vê-se aí um posicionamento da Corte, por meio do qual esta restringia os poderes do Congresso, ao interpretar, pela lei antitruste, comércio como transporte não como produção, claramente tornando-se receptiva às modificações inseridas no cenário econômico estadunidense da época. Dava-se interpretação extensiva à lei quando esta servia ao capital financeiro, todavia, era-lhe dada interpretação restritiva caso esta lhe tolhesse a sanha.

Contudo, não adotava a Suprema Corte posicionamento unânime no enfrentamento das questões postas sobre o cenário do constitucionalismo laissez-faire. No caso Swift and Co. v. United States (1905), em que discutido o monopólio da carne exercido pela companhia Swift, aplicou-se a Lei Sherman para considerar como o exercício indevido de truste, à corrente de comércio entre os Estados, no tocante ao curso estabelecido nos negócios intraestaduais da carne, com finalidade de regular preços e estabelecer regras uniformes de crédito a atingirem a órbita interestadual, justificariam o controle do Governo central sobre eles.

Tendo sido o Justice Holmes o redator do referido acórdão, nas palavras de Rodrigues, lá se compreendeu o comércio entre os Estados a partir de uma concepção de que ao tráfico propriamente dito, se amoldavam outras atividades relacionadas ao curso do negócio: "a aplicação da cláusula de comércio da Constituição no caso Swift foi o resultado do desenvolvimento natural do comércio interestadual em condições modernas" (RODRIGUES, 1992, p. 125). 
Embora tendo variado a jurisprudência, a tendência dominante da Corte era pela restrição dos poderes do Congresso, em prol do arrojo econômico implementado como política de crescimento financeiro dos Estados Unidos. O caso Hammer v. Dagenhart (1918) é bastante ilustrativo desta postura.

A Lei do Trabalho Infantil de $1916^{11}$ foi editada pelo Congresso, tendo como base a cláusula constitucional que lhe conferia poderes para regulamentar o comércio interestadual, pelo que, a partir de sua edição, passou o Governo central a restringir a exploração do trabalho infantil, assim, por exemplo, impondo a proibição de venda no comércio interestadual de bens produzidos pelas fábricas que empregavam crianças menores de 14 anos.

Vê-se que, neste julgado, a Suprema Corte manejou o devido processo legal substancial para adotar rigorosamente um conceito de equilíbrio entre os Estados e a União, ajustado à doutrina laissez-faire, completamente adequada ao pensamento político daquela época. Schwartz assim explica:

\begin{abstract}
Hammer v. Dagenhart ajustava-se perfeitamente à teoria do laissez-faire da função governamental que dominava o pensamento político e econômico dos Estados Unidos antes da grande depressão no início da década de 1930. Proibir a intervenção federal num caso como o do trabalho dos menores era excluir a possibilidade de qualquer regulamentação efetiva a respeito do assunto. Isto, de fato, era exatamente o que exigiam os defensores do laissez-faire. (SCHWARTZ, 1966, p. 69)
\end{abstract}

A Suprema Corte, naquele caso, invalidou a lei federal, sob o entendimento que, por esta norma, teria o Congresso dado abrangência à cláusula de comércio, igualando condições e, com isto, usurpando os poderes do governo local. Desta posição da Corte divergia o Justice Holmes. Entendia ele, em festejado voto vencido, que a lei, de fato, não deveria se intrometer nos assuntos dos Estados e que a estes cabia o poder de regulamentar seus negócios internos, contudo, ao remeterem seus produtos a outros Estados da federação, estariam sujeitos ao balizamento do Governo Central, sobretudo quando em tela a restrição ao prematuro e aviltante trabalho infantil (RODRIGUES, 1992, p. 127)

\title{
3.3 O devido processo legal substancial, a regulamentação de tarifas e outras práticas discriminatórias
}

Em Smyth v. Ames, (1898), no que tange à ingerência do Estado de Nebraska sobre a fixação de tarifas no transporte ferroviário interestadual, a Suprema Corte sustentou o

\footnotetext{
11 Keating-Owen Child Labor Act. (1916). Disponível em: <http://www.ourdocuments.gov/doc.php?doc=59\&page=transcript $>$. Acesso em 03.dez.2015
} 
entendimento de que as empresas ferroviárias seriam pessoas na acepção da $14^{\mathrm{a}}$ Emenda, julgando, conquanto, que nenhum Estado estaria habilitado em privar qualquer 'pessoa' de sua propriedade sem o devido processo legal, nem negar a qualquer pessoa dentro de sua jurisdição a igual proteção das leis.

A cláusula do devido processo legal substancial fora manejada no sentido de balizar o exame feito pelo Tribunal acerca da regulamentação pública de tarifas de transporte de um Estado para outro, no sentido de fazê-lo mediante critérios de seu "valor presente", mediante avaliação do custo de sua reprodução, à análise de ser a tarifa razoável e de permitir ao concessionário do respectivo serviço "justa retribuição, em face da justa avaliação de seu investimento (RODRIGUES, 1992, p. 141).

Vê-se o uso do "valor presente" - como base valorativa para se atingir a razoabilidade de determinada disposição normativa, no manejo da cláusula do devido processo legal substancial -, como técnica de julgamento utilizada pela Suprema Corte para intervir na fixação de tarifas de serviços públicos, numa clara atuação do constitucionalismo laissez-faire, de uma Corte influenciada pelo ideário liberal que a conduziu durante seu terceiro período: "visando restringir toda a regulamentação econômica, a interpretação dada à cláusula de due process representou, também, sério obstáculo à fixação de preços" (RODRIGUES, 1992, p. 142).

Situação paradoxal é revelada no julgamento dado pela Suprema Corte no caso Plessy v. Fergusson (1896). Com efeito, aquele entendimento sobre o qual examinada a $14^{\mathrm{a}}$ Emenda ante o entendimento de que seria inconstitucional legislação estadual que negasse a qualquer pessoa (neste conceito de pessoas inseridas as corporações e companhias ferroviárias), dentro de sua jurisdição, a igual proteção das leis, não abarcou tal juízo da Corte as situações em que provocada para se posicionar acerca das práticas discriminatórias raciais. De fato um paradoxo.

Curiosamente, aquele serviço ferroviário, cujos custos tarifários tiveram o amparo da igual proteção das leis, num manejo afrouxado do devido processo legal, não iria ser alvo do mesmo juízo de razoabilidade no que tange à acomodação em separado de brancos e negros nos vagões de trem.

Foi exatamente à sombra da cláusula de igual proteção que Plessy, negro do Estado da Louisiana, tendo sido coagido, numa viagem de trem, a ocupar um compartimento 
separado para os de sua cor, alegou que a separação de vagões feria a $13^{\text {a }}$ Emenda que aboliu a escravidão, bem como a $14^{\mathrm{a}}$ Emenda que proibia a legislação discriminatória por parte dos Estados. Com efeito, muito embora tivesse pago uma passagem para viajar em primeira classe, findou por ser retirado à força do vagão que ocupava e conduzido à prisão de New Orleans, devido à sua resistência em acatar aquela ordem. Em sua defesa, afirmara Plessy estar a lei do Estado da Luisiana, a prever vagões separados para brancos e negros, em conflito com a Constituição dos Estados Unidos.

Chegando o caso à Suprema Corte, esta o distinguiu a partir do entendimento de que o objeto da $14^{\mathrm{a}}$ Emenda, qual seja o de estabelecer uma igualdade absoluta das duas raças perante a lei, não poderia ser interpretada extensivamente no sentido de abolir as distinções evidenciadas pela cor da pele, impondo uma mistura de raças que consistisse em situações vexatórias para ambas ${ }^{12}$.

Desde que acomodados em situações semelhantes, nada impediria que brancos e negros estivessem separados. Era o dogma da política do separate, but equal, cunhada por décadas pelos tribunais americanos ${ }^{13}$, que vigorou também no tratamento das causas relacionadas à educação, validando leis estaduais que destinassem escolas iguais, mas separadas, para brancos e negros ${ }^{14}$.

\subsection{O devido processo legal substancial e o novo federalismo}

Até agora é possível ver uma certa linha de coerência nas decisões da Suprema Corte, mesmo em um ou outro posicionamento dissonante, a demonstrar um entendimento sobre o qual concede aos Estados autonomia para gerirem suas questões internas, livres da ingerência do Governo central que, ao seu turno, teria também assegurado seu centro de

\footnotetext{
${ }^{12}$ Bernard Schwartz faz apropriada análise da atuação da Suprema Corte no que tange ao manejo daquela doutrina: "De 1896, quando foi anunciada pela primeira vez, a 1954, a doutrina de Plessy v. Ferguson foi sistemàticamente adotada pelo mais alto tribunal americano. $O$ fato de que a Suprema Côrte federal, durante êsse período, não foi tão longe a ponto de reformar a decisão no caso Plessy não significa, porém, que ela não tinha capacidade para tomar medidas importantes no sentido de melhorar a posição legal do negro dentro dos limites dêsse caso. Devemos lembrar que no caso Plessy v. Fergusson, a Côrte sustentou que a segregação das raças não violava qualquer proibição constitucional onde as leis que exigiam a segregação reconhecida legalmente só era válida se as acomodações estabelecidas para os negros fossem substancialmente iguais àquelas reservadas aos membros da ração branca. Na prática real, o negro americano tem recebido coisa muito diferente do que se considera tratamento igual no que concerne a acomodações separadas que lhe são reservadas. A observância rigorosa da exigência de igualdade nas acomodações requereria conseqüentemente uma melhoria substancial na condição do negro, mesmo se a segregação, como tal, fôsse ainda constitucionalmente tolerada". (SCHWARTZ, 1966, p. 288-289)

${ }^{13}$ No caso Plessy v. Ferguson, que consagrou tal doutrina no âmbito nacional, votou vencido o Juiz HARLAN, sustentando ser "a Constituição americana cega quanto às côres". Na sua opinião, disse ainda, ficaria mais tarde provado que êsse julgamento fora tão pernicioso quanto o do caso Dred Scott (RODRIGUES, 1992, p. 146)

${ }^{14}$ Cumming v. Richmond County Board of Education 175 U.S. 528 (1899)
} 
poder, porquanto interpretada a Constituição Federal sob parâmetros de uma doutrina de notificação judicial, onde eventuais restrições a liberdades contratuais, deveriam ser justificadas por serem estritamente necessárias. Esta era a tônica do federalismo dualista, a moldar a hermenêutica advinda do substantive due processo of law.

O caso do trabalho infantil, tratado logo mais acima, tem esta função ilustrativa de acenar uma ideologia sobre a qual se cunhava a ação governamental voltada especialmente ao plano local. Isto é sintetizado por Schwatz:

\begin{abstract}
Antigamente, o Govêrno era principalmente regulamentador e negativo: a sua tarefa principal (além da defesa) era manter o círculo e conservar a imparcialidade enquanto os interesses privados se afirmavam livremente. Hoje em dia, o Govêrno se interessa principalmente pela administração dos serviços sociais e se tornou positivo num novo sentido. (SCHWARTZ, 1966, p. 207)
\end{abstract}

Por outro lado, quando o Governo passa a estender suas ações para o campo social e econômico, em escala nacional, isto se dá devido a uma mudança de rumos pela qual passaram a condução política dos Estados Unidos, no rescaldo da Grande Depressão, o que, logicamente, refletiu em sua Suprema Corte. De fato, era hora de se adotar políticas públicas que permitissem maiores poderes à União a fim de que esta pudesse intervir numa federação mergulhada em uma derrocada financeira. Eram necessárias novas medidas regulamentadoras, um 'novo acordo' que possibilitasse a que o sistema americano retomasse seu crescimento. Era a política do New Deal, inaugurada com a Lei de Recuperação da Indústria Nacional de 1933, e outros códigos de concorrência leal (SCHWARTZ, 1966, p. 208), ocupando o que antes dava lugar ao laissez-faire, a exigir do Poder Judiciário estadunidense uma nova concepção para o federalismo.

É certo que adaptar a Suprema Corte à necessidade de regulamentação nacional do sistema econômico não foi tarefa fácil, o que só foi acontecer efetivamente após o ano de 1937. Antes disto, a Corte foi instada a se pronunciar no caso Schechter Poultry Corp. v. United States (1935), no qual se discutia a constitucionalidade da Lei de Recuperação da Indústria Nacional de 1933.

Tratava o caso de empresa de Nova York, que vendia, a grosso, aves vivas para um abatedouro de aves no Brooklyn, e que foi acusada de infringir o Código de Aves Domésticas Vivas, ferindo-lhe disposição concernente à regulamentação salarial e horas máximas de trabalho lá delineadas, bem como praticando concorrência desleal (SCHWARTZ, 1966, p. 208). 
A Corte respondeu que, muito embora pudesse o Governo central, em meio a uma crise económica, exigir medidas extraordinárias, como aquelas estabelecidas nos parâmetros da nova lei, cuja constitucionalidade se apurava, não poderia, ainda que sob este contexto, criar ou ampliar o poder constitucional que lhe era definido. Assim, ainda opondo-se à política do New Deal, a Suprema Corte, firmou propósito em defender a doutrina do duplo federalismo, ao entender, neste novo contexto, excedido o poder do Congresso em regular o comércio interestadual.

A Suprema Corte, avessa às políticas regulamentadoras - como se depreende de sua atuação nesta terceira fase que vai de 1895 a 1937 -, fazia uso do devido processo legal substancial como ferramenta hermenêutica para justificar a ausência de razoabilidade de quaisquer atos normativos que pudessem ser obstáculo à expansão capitalista, e assim pusesse em risco a proteção à propriedade e à liberdade de contratar ${ }^{15}$. Era a $14^{\mathrm{a}}$ emenda manobrada para justificar a proteção às liberdades de mercado.

Todavia, colocado em ação o programa de combate à crise financeira que assolava o país, deflagrada pelo conjunto de fatores que fizeram romper a grande depressão da economia norte-americana, como visto, o Governo central não encontrou na Suprema Corte receptividade à sua nova política. Foi necessário provocá-la com uma legislação que, alterando sua composição interna - um membro adicional poderia ser acrescentado à Corte, por cada Justice que inteirasse os 70 anos de idade (BAUM, 1985, p. 41) -, permitisse a mudança de seu perfil com o ingresso de magistrados de postura mais aberta às novas políticas.

Estabelecido o conflito entre a Corte e o legislador, seguiu-se a isto uma acentuada mudança de postura de seus membros no que tange a receptividade do New Deal, acrescido do fato de que alguns juízes findaram por renunciar aos seus cargos, o que de fato possibilitou uma reestruturação do pensamento da Suprema Corte: "the switch in time that saved nine" (BAUM, 1985, p. 41).

Despede-se a doutrina do constitucionalismo laissez-faire, para que, em seu lugar, passe a Suprema Corte a adotar uma posição mais comedida em relação às questões econômicas, uma doutrina de moderação judiciária, fundamental para que se inaugurasse uma atuação mais voltada às questões relacionadas às liberdades civis. Pode-se dizer que, a partir

\footnotetext{
${ }^{15}$ Nos anos 20, a Corte Suprema declarou inconstitucionais mais de 130 leis regulamentadoras. As leis federais foram derrubadas porque a Corte as via não como apoiadas pelas garantias de poderes dadas ao Congresso pela Constituição e as leis estaduais e municipais foram derrubadas principalmente como violações dos direitos econômicos protegidos pela Décima-Quarta emenda. (BAUM, 1985, p. 41)
} 
de 1937, a Suprema Corte adota a posição que era acenada nos votos vencidos do juiz Holmes, para o qual, criticando a permissividade de seus pares, a razoabilidade e a sensatez, exigidas no manejo do devido processo legal, não poderiam prescindir da racionalidade. Curtis sintetiza o pensamento daquele Magistrado, transcrevendo-lhe um comentário:

Há cerca de setenta e cinco anos eu aprendi que não era Deus. E assim, quando os habitantes dos vários estados desejam fazer alguma coisa que a Constituição não proíbe expressamente, eu digo, quer eu goste ou não: - Que se danem, se querem fazer que o façam! (CURTIS, apud, SCHWARTZ, 1966, p. 260)

As decisões que doravante passaram a aceitar a política do New Deal, inauguraram uma política de ativismo judicial a reconfigurar uma Suprema Corte que, aos poucos, retira da pauta principal a preocupação com as questões econômicas, passando a deter-se na interpretação constitucional para delineamento dos direitos civis. 


\section{CONSIDERAÇÕES FINAIS}

O desenvolvimento da jurisprudência da Suprema Corte, no controle pelo judiciário da atividade legislativa, tem assumido, ao longo de sua existência, diversos aspectos. Especialmente no final do século XIX e início do século XX, ou seja, entre os anos de 1895 a 1937, esta abordou a atividade legislativa da União e dos Estados a partir da adoção de uma ideologia de extrema proteção ao mercado, que absorveu como objetivo primordial de sua política jurisdicional, assim blindando a Constituição americana contra qualquer assédio legislativo que lhe pudesse atribuir outros significados que não aqueles concernentes à política do laissez-faire.

A constitucionalização do laissez-faire econômico trazia a reboque decisões tomadas pela Suprema Corte no sentido de limitarem a atuação estatal frente às liberdades de contrato e às liberdades de comércio, pelo que dotaram o conceito de liberdade de sentido quase que puramente econômico. É o que se extrai das decisões examinadas neste trabalho que, ao seu turno, não pretendem exaurir, mas ilustrar esta constatação.

Para esta distinção, lançou mão o Tribunal, do devido processo legal substancial como metodologia interpretativa das disposições normativas que lhe eram submetidas a partir de um esquema de revisão judicial, na perspectiva da lançá-las sob o filtro que se punha como estratégico, no que tange à defesa dos interesses econômicos, segundo aquela conjuntura histórica protagonizada pela sociedade americana. Os anos de reconstrução e riqueza, seguidos da constituição ideológica de um perfil self made man estadunidense.

Nesta intenção, aquela Casa necessitava justificar uma política de mercado que ascendia o individualismo econômico a parâmetros pelos quais se erigia uma conexão quase total entre igualdade e igualdade econômica e entre liberdade e liberdade de contrato, de maneira que o uso do devido processo legal substancial vinha em socorro desta tarefa para conferir àquela política um molde de constitucionalidade.

É certo que dotar de significado o devido processo legal, no aspecto da dimensão substancial dessa garantia, não é tarefa das mais fáceis, uma vez que reduzi-lo a um conceito, perpassa necessariamente pela acepção do que seja uma solução jurídica justa, dentro de uma graduação de justiça que necessariamente está ligada a contingentes históricos relacionados ao desenvolvimento do pensamento humano.

Assim, nesta empreitada, concebe-se o devido processo legal substancial a partir de sua capacidade de assumir uma performance moldável a distintas contextualizações, como o 
que se vê de seu manejo pela Suprema Corte norte-americana, dentro do recorte histórico estudado.

Quando o caso Dred Scott (1856), por exemplo, permitiu que se examinasse constitucionalmente a questão da liberdade de um escravo sob um viés puramente econômico, medindo-a não pela régua do humanitarismo, mas subjugando-a a proteção da propriedade privada, aí estava esboçado o contorno da índole judicante que a Suprema Corte adotaria em sua fase seguinte, a era Lochner.

Estavam, de fato, abertas as portas para um constitucionalismo laissez-faire, no qual foi a cláusula do devido processo legal substancial verdadeiro guideline onde se concretizaram judicialmente valores pelos quais se buscava coibir a atuação estatal restritiva dos direitos econômicos. 


\section{REFERÊNCIAS}

BAUM, Lawrence. A Suprema Corte Americana. Rio de Janeiro: Editora Forense Universitária, 1985

BEARD, Charles A. A Suprema Corte e a Constituição. Rio de Janeiro: Companhia Editora Forense, 1962.

CORWIN, Edward S. A Constituição Americana e seu Significado Atual. Rio de Janeiro: Zahar Editores, s/d.

ESTADOS UNIDOS DA AMÉRICA. Suprema Corte. Santa Clara County v. Southern Pacific R. Co., 118 U.S. 394_(1886)

Suprema Corte. Muller v. Oregon, 208 U.S. 412 _(1908)

Suprema Corte. Lochner v. New York, 198 U.S. 45 _(1905)

Suprema Corte. Holden v. Hardy, 169 U.S. $366 \_$(1898)

Suprema Corte. Mugler v. Kansas, 123 US 623 _(1887)

Suprema Corte. United States v. E. C. Knight Co., 156 U.S. 1 _(1895)

Suprema Corte. Loewe v. Lawlor, 208 U.S. 274 _(1908)

Suprema Corte. Adair v. United States, 208 U.S. 161

Suprema Corte. Swift \& Co. v. United States, 196 U.S. 375

Suprema Corte. Hammer v. Dagenhart, 247 U.S. 251 _(1918)

Suprema Corte. Smyth v. Ames, 169 U.S. $466 \_$_(1898)

Suprema Corte. Plessy v. Ferguson, 163 U.S. 537 _(1896) (1899)

Suprema Corte. Cumming v. Richmond County Board of Education, 175 U.S. 528

Suprema Corte. A. L. A. Schechter Poultry Corp. v. United States, 295 U.S. 495 
(1935)

_Sherman Antitrust Act _(1890) Disponível em:

http://www.linfo.org/sherman_txt.html. Acesso em: 02.dez.2015

Keating-Owen Child Labor Act. - (1916). Disponível em: http://www.ourdocuments.gov/doc.php?doc=59\&page=transcript. Acesso em 03.dez.2015

RODRIGUES, Lêda Boechat. A Corte Suprema e o Direito Constitucional Americano. Rio de Janeiro: Editora Civilização Brasileira, 1992.

SCHWARTZ, Bernard. Direito Constitucional Americano. Rio de Janeiro: Forense, 1966. 